\title{
P-27 RELATIONSHIPS BETWEEN DIAGENESIS AND POROSITY IN NORIAN-HETTANGIAN CARBONATE PLATFORMS - SUBSURFACE, PO VALLEY, ITALY
}

P. RONCHI

Eni SpA Agip Division, Via Emilia 1, 20097 San Donato Milanese, Italy

The Norian-Hettangian carbonate succession is one of the main hydrocarbon target of the Po Valley subsoil.

In the Mesozoic paleohigh, located in the central-western sector of the Po Valley, this succession consists of the following stacked carbonate platforms: Dolomia Principale, Campo dei Fiori and Conchodon Dolomite Fms.

The area belonged to the western margin of the Lombardy Basin which, from Triassic to Cretaceous times, was a structural paleohigh, characterised by condensed and lacunose carbonate series. Each Norian to Hettangian carbonate platforms represent a sedimentary sequence separated by subaerial hiatus (Fig. 1. Jadoul et al., 1994).

This work focuses on the stratigraphy, diagenesis and petrophysical properties of these carbonate platforms; the study has been performed on a continuous coring that sampled the whole succession, data from the several wells in the area have been also used: The petrographic study was conducted on several thin sections using also cathodoluminescence and SEM, diagenetic history has been reconstructed considering more than 180 measures of stable isotopes $\left(\delta^{13} \mathrm{C}\right.$ and $\left.\delta^{18} \mathrm{O}\right)$ and trace elements; fluid inclusion data helped to fit the diagenetic phase with the geohistory diagram reconstructed for the studied area.

The whole succession constitutes a reservoir where a network of tectonic fractures assure a high permeability, while the porosity and therefore the oil in place are strictly tied to the diagenetic history suffered by the reservoir formations; nevertheless the porosity shows important variations in term of pore network distribution and values. Petrographic and geochemical study evidenced that the petrophysical characteristics of the different units are strongly connected to the diagenetic overprint. 


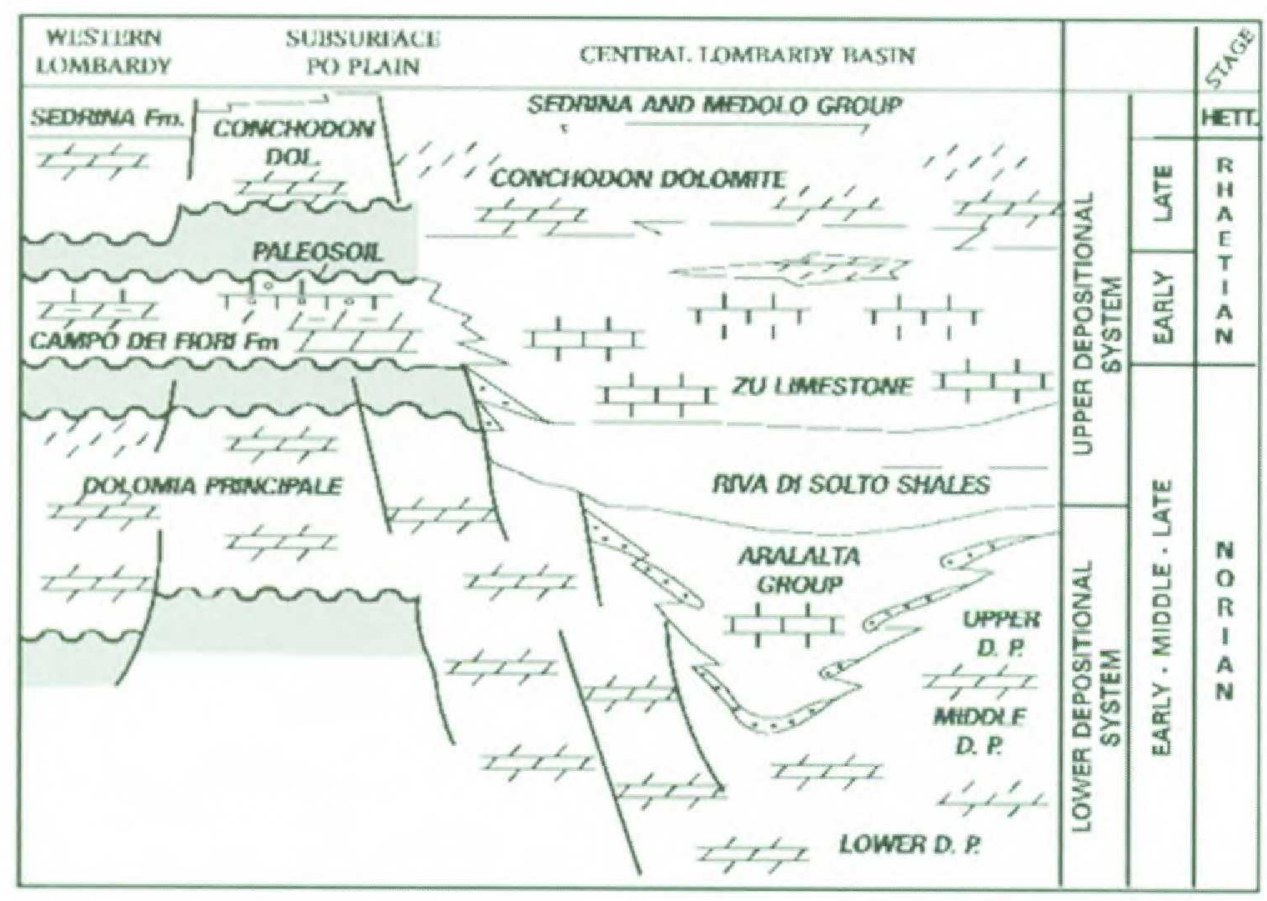

Fig. 1 - Stratigraphic scheme.

The Dolomia Principale (Lower-Middle Norian) lays in paraconformity on the calcareous series of the inter-platform basin of the Calcare di Meride (Ladinian) and only locally Carnian continental sandstones are intercalated. In the area studied, as well as in the outcrops of the western Lombardy region, the Dolomia Principale maintains conditions of low subsiding peritidal platform (thickness $<100 \mathrm{~m}$ ).

On the whole the formation represent a shallowing upward sequence made of subtidal and peritidal facies consisting in thin bedded fine grained dolomite layers. The lower part of the formation is constituted of subtidal sediments while upwards peritidal cycles are more and more frequent and few thin layers of green clay dolomite can be found locally between each cycle.

Geochemical and petrographic data indicate an early dolomitization, related to tidal flat environment the $\delta^{13} \mathrm{C}$ values shows a cyclic pattern corresponding to the peritidal alternations with negative values in the supratidal facies and positive ones in the subtidal units. To the mimic and fine-grained dolomite corresponds a compact and little porous dolostone that needs a fracture contribution .

The Campo dei Fiori Fm (Lower Rhaetian) made of lagoon and shoal deposits with minor periodic shale input, has a lower dolomitized unit and an upper calcareous one. The coarse dolomite texture, microfacies destructive, shows an intercrystalline porosity and scattered minor vugs. The calcareous unit is made of stacked shoal bars with oolithic grainstone at the top. The prolonged emersion at the Campo dei Fiori Dolomite top, testified by a thick paleosoil and its related meteoric diagenesis, strongly affected the underlying sediments. The $\delta^{13} \mathrm{C}$ signature, the trace elements and the cathodoluminescence features indicate that a thick freatic fresh water lens established during the emersion phase (Fig. 2. Lohmann, 1988). 


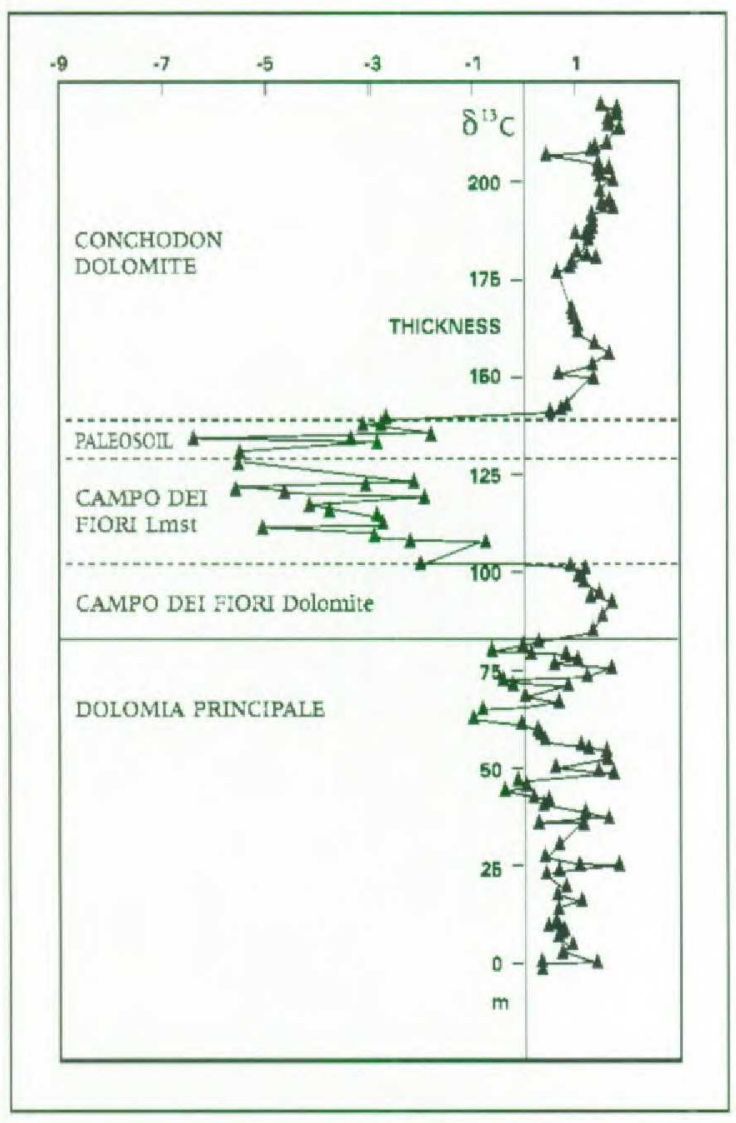

Fig. $2-\delta^{l 3} C$ values vs depth.

The petrophysical effect of meteoric diagenesis was the formation of oomoldic porosity that, in spite of moderate values, has low connectivity.

With the following transgression, the Conchodon Dolomite (uppermost Rhaetian-Hetangian) carbonate platform established with sedimentary feature changing from tidal flat at the base, to open lagoon environment toward the top. The carbonate platform may have continued for part of the Hettangian time as it is documented in other analogue paleohighs of the Lombardy Basin, where the flooding occurred later than in the subsiding areas. The Conchodon Dolomite was subject to a pervasive and fabric destructive dolomitization, developing an intercrystalline moldic and vuggy porosity.

The complex diagenetic history of this unit includes also strong recrystallization and burial dissolution which contributed to the vugs formation and fracture allargement: the role of mesodiagenes resulted the key to the reservoir formation (Mazzullo and Harris, 1992).

The diagenetic study of this succession evidenced that the Rhaetian-Hettangian paleohigh series, made of pervasive coarse grained late diagenetic dolomite, have better reservoir characteristics than the early dolomitized Norian ones (Fig. 3). The ending of the early tidal dolomitization at the Norian- Rhaetian boundary time, is probably linked to a change in the oceanic water circulation and paleoclimate in the Southern Tethys margin and was already stressed by other authors (Frisia and Iannace, 1994). This fact has a practical consequence in hydrocarbon exploration in the South Alpine region: the Norian fine grained, compact, dolomite texture needs a strong fracturing contribution to be reservoir, while the rhaetian-hettangian platform facies developed a later diagenetic dolomitization that improved the primary porosity, causing a reservoir rock with fairly porous matrix. 


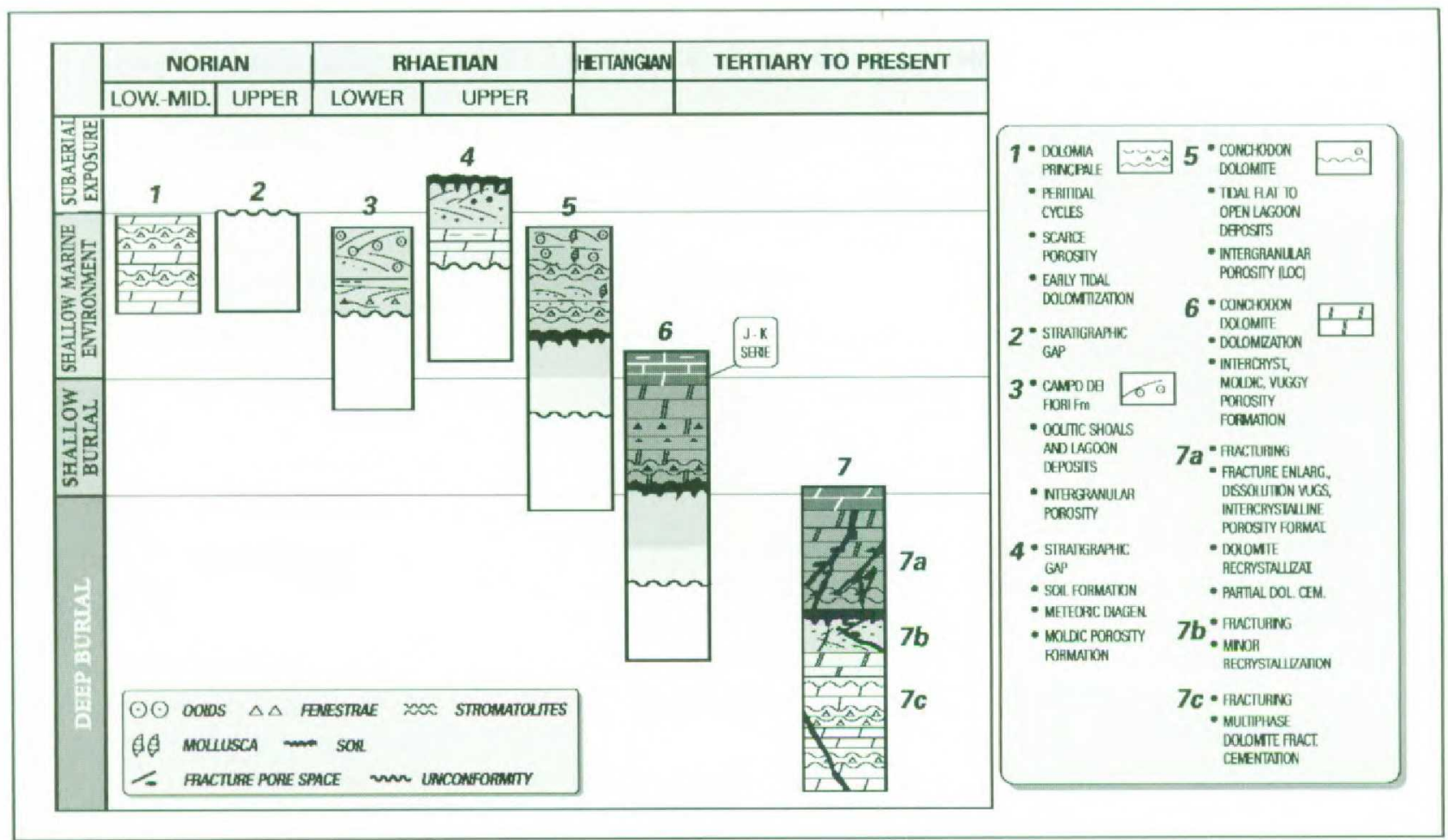

Fig. 3 - Diegenetic steps

\section{Cited references}

Jadoul F., Masetti D., Cirilli S., Berra F., Claps M.\& Frisia S. (1994). Norian_Rhaetian

Stratigraphy and Paleogeographic evolution of the Lombardy Basin (Bergamasc Alps). In

G. Carannante \& R. Tonielli (Eds.), IAS 15th Regional meeting, Ischia, Fieldtrip Guidebook,

Excursion B1, pp. 3-38.

IANNACE A. AND FRISIA S., (1994). Changing dolomitization styles from Norian to Rhateian in the Southern Tethys realm. Spec. Publs Int. Ass. sediment., v. 21, pp. 75-89.

LOHMANN K.C., (1988). Geochemical patterns of meteoric diagenetic systems and their applications to studies of paleokarst. In: paleokarst (Ed. by N.P. James and P.W. Choquette) pp. 58-80. Springer-Verlag, New York.

Mazzullo J.S. And Harris P.M., (1992). Mesogenetic Dissolution: Its role in porosity development in Carbonate Reservoirs. AAPG Bull., v. 76, n.5, pp. 607-620. 